EDITORIAL

\title{
Policy decisions on endocrine disruptors should be based on science across disciplines: a response to Dietrich et al.
}

\begin{abstract}
A C Gore ${ }^{1}$, J Balthazart ${ }^{2}$, D Bikle ${ }^{3}$, D o Carpenter ${ }^{4}$, D Crews ${ }^{5}$, P Czernichow ${ }^{6}$, E Diamanti-Kandarakis ${ }^{7}$, R M Dores ${ }^{8}$, D Grattan $^{9}$, P R Hof ${ }^{10}$, A N Hollenberg ${ }^{11}$, C Lange ${ }^{12}$, A V Lee ${ }^{13}$, J E Levine ${ }^{14}$, R P Millar ${ }^{15}$, R J Nelson ${ }^{16}$, M Porta ${ }^{17}$, $\mathrm{M} \mathrm{Poth}^{18}$, D M Power ${ }^{19}$, G S Prins ${ }^{20}$, E C Ridgway ${ }^{21}$, E F Rissman ${ }^{22}$, J A Romijn ${ }^{23}$, P E Sawchenko ${ }^{24}$, P D Sly ${ }^{25}$, O Söder $^{26}$, H S Taylor ${ }^{27}$, M Tena-Sempere ${ }^{28}$, H Vaudry ${ }^{29}$, K Wallen ${ }^{30}$, Z Wang ${ }^{31}$, L Wartofsky ${ }^{32}$ and C S Watson ${ }^{32,33}$

${ }^{1}$ Division of Pharmacology and Toxicology, The University of Texas, Austin, Texas 78712, USA, ${ }^{2}$ GIGA Neurosciences, University of Liege, B-4000 Liege, Belgium, ${ }^{3}$ VA Medical Center, University of California, San Francisco, California 94143, USA, ${ }^{4}$ Institute for Health and the Environment, University at Albany, State University of New York, Albany, New York 12222, USA, ${ }^{5}$ Section of Integrative Biology, University of Texas, Austin, Texas 78712 , USA, ${ }^{6}$ Professor Emeritus of Pediatrics, University of Paris, 75006 Paris, France, ${ }^{7}$ Medical School, Sotiria Hospital, University of Athens, Athens 11527 , Greece, ${ }^{8}$ Department of Biological Sciences, University of Denver, Denver, Colorado 80208, USA, ${ }^{9}$ Department of Anatomy, University of Otago, North Dunedin 9016, New Zealand, ${ }^{10}$ Icahn School of Medicine at Mount Sinai, New York, New York 10029, USA, ${ }^{11}$ Harvard Medical School, Beth Israel Deaconess Medical Center, Boston, Massachusetts 02115, USA, ${ }^{12}$ Masonic Cancer Center, University of Minnesota, Minneapolis, Minnesota 55455 , USA, ${ }^{13}$ Cancer Institute and Magee Women's Research Institute, University of Pittsburgh, Pittsburgh, Pennsylvania 15213, USA, ${ }^{14}$ Wisconsin National Primate Research Center, Madison, Wisconsin 53715, USA, ${ }^{15}$ UCT/MRC Receptor Biology Unit, University of Cape Town, Cape Town, South Africa, ${ }^{16}$ Department of Neuroscience, Wexner Medical Center, The Ohio State University, Columbus, Ohio 43210, USA, ${ }^{17}$ School of Medicine, Hospital del Mar Institute of Medical Research (IMIM), Universitat Autonoma de Barcelona, 080041 Barcelona, Spain, ${ }^{18}$ Uniformed Services University of the Health Sciences, Bethesda, Maryland 20814, USA, ${ }^{19}$ Department of Biosciences, Universidade do Algarve, 8005-139 Faro, Portugal, ${ }^{20}$ Department of Physiology and Biophysics, University of Illinois, Chicago, Illinois 60612, USA, ${ }^{21}$ Department of Medicine, School of Medicine, University of Colorado, Denver, Colorado 80208, USA, ${ }^{22}$ Department of Biochemistry and Molecular Genetics, School of Medicine, University of Virginia, Charlottesville, Virginia 22908, USA, ${ }^{23}$ Division of Medicine, Academic Medical Center, University of Amsterdam, 1012 WX Amsterdam, The Netherlands, ${ }^{24}$ Laboratory of Neuronal Structure and Function, The Salk Institute, La Jolla, California 92037, USA, ${ }^{25}$ Queensland Children's Medical Institute, Royal Children's Hospital, University of Queensland, Brisbane, Queensland 4000, Australia, ${ }^{26}$ Karolinska Institutet, Karolinska University Hospital, 17176 Solna, Stockholm, Sweden, ${ }^{27}$ Department of Obstetrics, Gynecology and Reproductive Sciences, Yale School of Medicine, New Haven, Connecticut O6510, USA, ${ }^{28}$ Department of Cell Biology and Physiology, University of Córdoba, 14071 Córdoba, Spain, ${ }^{29}$ Institut National de la Santé et de la Recherche Médicale U982, University of Rouen, 76821 Rouen, France, ${ }^{30}$ Department of Psychology, Yerkes National Primate Research Center, Emory University, Atlanta, Georgia 30322, USA, ${ }^{31}$ Department of Psychology and Neuroscience, Florida State University, Tallahassee, Florida 32306 , USA, ${ }^{32}$ Department of Medicine, Washington Hospital Center, Washington, District of Columbia 20010, USA and ${ }^{33}$ Department of Biochemistry and Molecular Biology, University of Texas Medical Branch, Galveston, Texas 77555, USA
\end{abstract}

(Correspondence should be addressed to A C Gore; Email: andrea.gore@austin.utexas.edu)

European Journal of Endocrinology 169 E1-E4

We are writing as scientists and editors of leading peer-reviewed journals that have published important contributions in the study of endocrine disrupting chemicals (EDCs). By signing this editorial, we affirm that regulatory decisions on EDCs should be made based on the best available science and expertise that involves, among others, reproductive biology, endocrinology, medicine, genetics, behavior, developmental biology, and toxicology (1). For a complete list of Signatories and their Disclosures, see Supplementary Table 1, see section on supplementary data given at the end of this article published on The Endocrine Society's Journals Online web site (http://end.endojournals.org).

Thousands of published studies have revealed the health effects of EDCs on wildlife and laboratory animals and, moreover, have shown associations of EDCs with effects in humans. Many of these studies have been reviewed recently by The Endocrine Society, the United Nations Environment Programme (UNEP) and World Health Organization (WHO), and other independent scientists $(2,3,4,5)$. The conclusions presented in each of these documents are extraordinarily consistent: like hormones, EDCs are active at very low doses and can induce a range of adverse health outcomes, many of which are not examined in traditional toxicology assays (1). In sum, these reports point to the conclusion that EDCs pose a global health threat.

A recent editorial signed by a number of editors of toxicology journals argues for the status quo in the regulation of EDCs (6), despite the large volume of evidence indicating that current regulations are ineffective in protecting human populations from these chemicals $(4,5,6,7)$. As the UNEP/WHO report notes, the incidence of chronic disease is now greater than that of communicable disease; many of these diseases have an endocrine basis. Both experimental animal and epidemiology studies provide plausible causal links between EDCs and many of these diseases; for some, the data are sufficiently robust (8).

The dismissive approach to endocrine disruption science put forth by Dietrich et al. (6) is unfounded, as it is neither based on the fundamental principles of how the endocrine system works and how chemicals can interfere with its normal function, nor does it consider 
the consequences of that interference. Their letter also ignores a growing and rigorous body of literature on both endogenous hormonal and exogenous EDC effects.

Basic scientists, clinical investigators, and physicians understand that the endocrine system's functions and responses change remarkably across the life cycle. Of particular concern is incontrovertible evidence, published more than a half century ago $(9,10)$, that there are critical life stages, especially during early development, when hormones dictate the differentiation and development of tissues. Any perturbation of the delicate hormonal balance, whether due to the absence of natural hormones or the presence of exogenous hormones, can have irreversible effects on endocrinesensitive organs. EDCs are known to upset this delicate balance.

Dietrich et al. (6) also misrepresent the state of science on thresholds, stating that the evidence "clearly demonstrates the presence of a threshold for nongenotoxic compounds including EDCs'. Dietrich et al. assert that their position constitutes 'common sense' and that the European Commission's approach departs from common sense. They do not, however, provide scientific support for this position. Instead, they list several references $(11,12,13,14,15)$ that, upon examination, do not contain data supporting their assumption but rather simply assert that the assumption is true. They also fail to address the considerable literature that speaks against that assumption (e.g. references (16, 17, $18,19,20)$ ). Finally, they argue that structuring regulation upon the assumption of no threshold 'will set an unforeseen precedence (sic)'. This is simply and demonstrably not true. The assumption of no threshold has been widely used, for many years, in the regulation of genotoxic carcinogens, often based on in vitro data. We believe extending this precedent to EDCs is supported by the science (19).

Furthermore, we hold that common sense dictates that policies, particularly those in which public health is at stake, should be based on scientific evidence obtained from the world's leading researchers and should derive from a more evolved, modern understanding of the science, rather than on older, outdated concepts and data taught in classrooms 20 or more years ago. The European Commission policy, by that standard, does represent 'common sense'.

Further, the USA National Academy of Sciences has concluded that because of the range of susceptibility to environmental chemicals across the population, such as that from age, preexisting conditions, and genetic variation, and because there are documented exposures to multiple chemicals, including EDCs, in the population, it is more appropriate to consider lack of thresholds at a population level (16).

Many toxicologists have developed rigorous research programs on EDCs that incorporate endocrinological principles, including two former presidents of the Society of Toxicology, Cheryl Walker and Linda
Birnbaum. They and many other toxicologists do work in this area and report results that have contributed to the breadth and depth of concern about EDCs as a global public health threat. The ad hominem attacks in Dietrich et al. (6) do nothing to advance science or opportunities to protect public health; we refer readers to two additional responses to their editorial that support this point of view $(21,22)$. We need the fields of toxicology, endocrinology and other stakeholders to work together to address these issues, not engage in recriminations.

Policymakers in Europe and elsewhere should base their decisions on science, not on assumptions based on principles that arose out of research on chemicals that are not EDCs. The letter by Dietrich et al. does the European Commission, science, including the field of toxicology, and most importantly, public health, a profound disservice.

\section{Signatories}

\section{Journal Editors-in-Chief}

1. Jacques Balthazart, PhD, Frontiers in Neuroendocrinology.

2. David O Carpenter, MD, Reviews on Environmental Health.

3. Paul Czernichow, MD, Hormone Research in Pediatrics.

4. Donald B DeFranco, PhD, Molecular Endocrinology.

5. Robert M Dores, PhD, General and Comparative Endocrinology.

6. Andrea C Gore, PhD, Endocrinology.

7. David Grattan, PhD, Journal of Neuroendocrinology.

8. Stephen R Hammes, MD, PhD, Editor-in-Chief elect, Molecular Endocrinology.

9. Patrick R Hof, MD, Journal of Comparative Neurology.

10. Carol Lange, PhD, Hormones and Cancer.

11. Jon E Levine, PhD, Frontiers in Neuroendocrinology.

12. Deborah M Power, $\mathrm{PhD}$, General and Comparative Endocrinology.

13. Robert P Millar, PhD, FRSE, Neuroendocrinology.

14. E Chester Ridgway, MD, MACP, Endocrine Reviews.

15. Johannes A Romijn, MD, PhD, European Journal of Endocrinology.

16. Peter D Sly, MBBS, FRACP, MD, DSc, Reviews on Environmental Health.

17. Hubert Vaudry, PhD, Dr Sci, Frontiers in Neuroendocrine Science; also Senior Editor, Journal of Neuroendocrinology; Associate Editor, Hormone and Metabolic Research; Associate Editor, General and Comparative Endocrinology; and Associate Editor, Peptides.

18. Kim Wallen, PhD, Hormones and Behavior.

19. Leonard Wartofsky, MD, MACP, Journal of Clinical Endocrinology and Metabolism.

20. Cheryl S Watson, PhD, Endocrine Disruptors. 


\section{Journal Associate Editors}

1. Åke Bergman, PhD, Archives of Environmental Contamination and Toxicology; Environmental Science and Pollution Research.

2. Daniel Bikle, MD, PhD, Endocrinology.

3. Barbara A Cohn, PhD, Endocrine Disruptors.

4. David Crews, PhD, Endocrine Disruptors; Journal of Experimental Zoology; Ecological Genetics and Physiology; Sexual Development; Epigenetics.

5. Peter L DeFur, PhD, Endocrine Disruptors.

6. Evanthia Diamanti-Kandarakis, MD, PhD, European Journal of Endocrinology.

7. Anthony N Hollenberg, MD, Endocrinology.

8. Susan Jobling, PhD, Endocrine Disruptors.

9. Jun Kanno, MD, PhD, Environmental Health Perspectives.

10. Carolyn Klinge, PhD, Endocrine Disruptors.

11. B Paige Lawrence, PhD, Endocrine Disruptors.

12. Adrian $\mathrm{V}$ Lee, $\mathrm{PhD}$, Endocrinology.

13. J P Myers, PhD, Endocrine Disruptors.

14. Randy J Nelson, PhD, Hormones and Behavior.

15. Miquel Porta, MD, MPH, PhD, Journal of Epidemiology and Community Health; European Journal of Clinical Investigation; European Journal of Epidemiology.

16. Merrily Poth, MD, Journal of Clinical Endocrinology and Metabolism.

17. Gail S Prins PhD, Endocrinology; Andrology.

18. Emilie F Rissman, $\mathrm{PhD}$, Endocrinology.

19. Paul E Sawchenko, PhD, Journal of Comparative Neurology.

20. Olle Söder, MD, PhD, Hormone Research in Pediatrics.

21. Ana M Soto, MD, Progress in Biophysics and Molecular Biology.

22. Shanna Swan, PhD, Endocrine Disruptors.

23. Hugh S Taylor, MD, Endocrinology.

24. Manuel Tena-Sempere, MD, PhD, Endocrinology.

25. Frederick vom Saal, $\mathrm{PhD}$, Endocrine Disruptors.

26. Zuoxin Wang, $\mathrm{PhD}$, Hormones and Behavior.

27. Wade V Welshons, $\mathrm{PhD}$, Endocrine Disruptors.

28. R Thomas Zoeller, PhD, Endocrine Disruptors.

\section{Additional Signatories}

1. Benson T Akingbemi, PhD.

2. Koji Arizono, PhD.

3. Scott M Belcher, PhD.

4. Fiorella Belpoggi, PhD.

5. Carl-Gustaf Bornehag, $\mathrm{PhD}$.

6. Jean-Pierre Bourguignon, MD, PhD.

7. Terry R Brown, $\mathrm{PhD}$.

8. Ernesto Burgio, MD.

9. Terrence J Collins, $\mathrm{PhD}$.

10. D Andrew Crain, PhD.

11. Barbara Demeneix, PhD.

12. Rodney R Dietert, PhD.

13. Loretta Doan, PhD.

14. Thea M Edwards, PhD.

15. Mariana F Fernandez, PhD.
16. R William Field, PhD, MS.

17. Linda C Giudice, MD, PhD.

18. Louis J Guillette, PhD.

19. Y Leon Guo, MD, PhD, MPH.

20. Tyrone Hayes, PhD.

21. Andrea Hinwood, PhD.

22. C Vyvyan Howard, MB, ChB, PhD, FRC Path.

23. Eric R Hugo, PhD.

24. Patricia Hunt, $\mathrm{PhD}$.

25. Taisen Iguchi, $\mathrm{PhD}$.

26. Richard J Jackson, MD, MPH, AIA (Hon), ASLA (Hon).

27. Patricia Joseph-Bravo, PhD.

28. Hans Laufer, $\mathrm{PhD}$.

29. Duk-Hee Lee, MD, PhD.

30. Rachel Morello-Frosch, PhD, MPH.

31. Jane Muncke, PhD.

32. Angel Nadal, $\mathrm{PhD}$.

33. David O Norris, $\mathrm{PhD}$.

34. Jörg Oehlmann, PhD.

35. Nicolas Olea, MD, PhD.

36. Edward F Orlando, PhD.

37. Vasantha Padmanabhan, PhD.

38. Paola Palanza, $\mathrm{PhD}$.

39. Stefano Parmigiani, PhD.

40. Donald W Pfaff, PhD.

41. Beverly S Rubin, PhD.

42. Joan V Ruderman, $\mathrm{PhD}$.

43. Arnold Schecter, MD, MPH.

44. Toshi Shioda, MD, PhD.

45. Martin Scheringer, $\mathrm{PhD}$.

46. Niels E Skakkebaek, MD.

47. Howard M Snyder III, MD.

48. Carlos Sonnenschein, MD.

49. Richard W Stahlhut, MD, MPH.

50. Laura Vandenberg, $\mathrm{PhD}$.

51. Catherine VandeVoort, $\mathrm{PhD}$.

52. Martin Wagner, $\mathrm{PhD}$.

53. Hong-Sheng Wang, PhD.

54. Bernard Weiss, PhD.

55. Teresa Woodruff, $\mathrm{PhD}$.

56. Tracey Woodruff, PhD.

\section{Supplementary data}

This is linked to the online version of the paper at http://dx.doi.org/ 10.1530/EJE-13-0763.

\section{Acknowledgments}

The following is the list of signatories. The complete list of their affiliations and disclosure information is provided in Supplemental Table 1 (see section on supplementary data given at the end of this article).

\section{References}

1 American Society of Human Genetics, American Society for Reproductive Medicine, Endocrine Society, Genetics Society of America, Society for Developmental Biology, Society for Pediatric 
Urology, Society for the Study of Reproduction, Society for Gynecologic Investigation. Assessing chemical risk: societies offer expertise. Science 2011331 1136. (doi:10.1126/science.331. 6021.1136-a)

2 Diamanti-Kandarakis E, Bourguignon JP, Guidice LC, Hauser R, Prins GS, Soto AM, Zoeller RT \& Gore AC. Endocrine-disrupting chemicals: an Endocrine Society scientific statement. Endocrine Reviews 200930 293-342. (doi:10.1210/er.2009-0002)

3 Vandenberg LN, Colborn T, Hayes TB, Heindel JJ, Jacobs DR Jr, Lee DH, Shioda T, Soto AM, vom Saal FS, Welshons WV et al. Hormones and endocrine-disrupting chemicals: low-dose effects and nonmonotonic dose responses. Endocrine Reviews 201233 378-455. (doi:10.1210/er.2011-1050)

4 Zoeller RT, Brown TR, Doan LL, Gore AC, Skakkebaek NE, Soto AM, Woodruff TJ \& vom Saal FS. Endocrine-disrupting chemicals and public health protection: a statement of principles from the Endocrine Society. Endocrinology 2012153 4097-4110. (doi:10.1210/en.2012-1422)

5 Eds Bergman A, Heindel JJ, Jobling S, Kidd KA \& Zoeller RT. State of the Science of Endocrine Disrupting Chemicals - 2012. An Assessment of the State of the Science of Endocrine Disruptors Prepared by a Group of Experts for the United Nations Environment Programme and World Health Organization. Geneva, Switzerland: United Nations Environment Programme and the World Health Organization, 2013.

6 Dietrich DR, Aulock SV, Marquardt H, Blaauboer B, Dekant W, Kehrer J, Hengstler J, Collier A, Gori GB, Pelkonen O et al. Scientifically unfounded precaution drives European Commission's recommendations on EDC regulation, while defying common sense, wellestablished science and risk assessment principles. Chemico-Biological Interactions 2013205 A1-A5. (doi:10.1016/j.cbi.2013.07.001)

7 Vandenberg LN, Colborn T, Hayes TB, Heindel JJ, Jacobs DR, Lee DH, Myers JP, Shioda T, Soto AM, vom Saal FS et al. Regulatory decisions on endocrine disrupting chemicals should be based on the principles of endocrinology. Reproductive Toxicology $2013 \mathbf{3 8}$ 1-15. (doi:10.1016/j.reprotox.2013.02.002)

8 Birnbaum LS. Environmental chemicals: evaluating low-dose effects. Environmental Health Perspectives 2012120 A143-A144. (doi:10.1289/ehp.1205179)

9 Phoenix CH, Goy RW, Gerall AA \& Young WC. Organizing action of prenatally administered testosterone propionate on the tissues mediating mating behavior in the female guinea pig. Endocrinology 195965 369-382. (doi:10.1210/endo-65-3-369)

10 Wallen K. The Organizational Hypothesis: reflections on the 50th anniversary of the publication of Phoenix, Goy, Gerall, and Young (1959). Hormones and Behavior 200955 561-565. (doi:10.1016/ j.yhbeh.2009.03.009)

11 Boobis AR, Daston GP, Preston RJ \& Olin SS. Application of key events analysis to chemical carcinogens and noncarcinogens. Critical Reviews in Food Science and Nutrition 200949 690-707. (doi:10.1080/10408390903098673)
12 Borgert CJ, Sargent EV, Casella G, Dietrich DR, McCarty LS \& Golden RJ. The human relevant potency threshold: reducing uncertainty by human calibration of cumulative risk assessments. Regulatory Toxicology and Pharmacology 201262 313-328. (doi:10.1016/j.yrtph.2011.10.012)

13 Piersma AH, Hernandez LG, van Benthen J, Muller JJ, van Leuven FX, Vermiere TG \& van Raaij MT. Reproductive toxicants have a threshold of adversity. Critical Reviews in Toxicology 2011 41 545-554. (doi:10.3109/10408444.2011.554794)

14 Rhomberg LR, Goodman JE, Haber LH, Dourson M, Andersen ME, Klaunig JE, Meek B, Price PS, McClellan RO \& Cohen SM. Linear low-dose extrapolation for noncancer health effects is the exception, not the rule. Critical Reviews in Toxicology $2011 \mathbf{4 1}$ 1-19. (doi:10.3109/10408444.2010.536524)

15 Rhomberg LR \& Goodman JE. Low-dose effects and nonmonotonic dose-responses of endocrine disrupting chemicals: has the case been made? Regulatory Toxicology and Pharmacology 201264 130-133. (doi:10.1016/j.yrtph.2012.06.015)

16 vom Saal FS \& Sheehan DM. Challenging risk assessment. Forum for Applied Research and Public Policy 199813 11-18.

17 Sheehan DM, Willingham E, Gaylor D, Bergeron JM \& Crews D. No threshold dose for estradiol-induced sex reversal of turtle embryos: how little is too much? Environmental Health Perspectives 1999107 155-159. (doi:10.1289/ehp.99107155)

18 Sheehan DM \& vom Saal FS. Low dose effects of hormones: a challenge for risk assessment. Risk Policy Report 19974 31-39.

19 Sheehan DM. No-threshold dose-response curves for nongenotoxic chemicals: findings and application for risk assessment. Environmental Research 2006100 93-99. (doi:10.1016/j.envres. 2005.09.002)

20 Welshons WV, Thayer KA, Judy BM, Taylor JA, Curran EM \& vom Saal FS. Large effects from small exposures. I. Mechanisms for endocrine-disrupting chemicals with estrogenic activity. Environmental Health Perspectives 2003111 994-1006. (doi:10.1289/ ehp. 5494)

21 Grandjean P \& Ozonoff D. Transparency and translation of science in a modern world. Environmental Health 20131270. (doi:10.1186/1476-069X-12-70)

22 Bergman A, Andersson AM, Becher G, van den Berg M, Blumberg B, Bjerregaard P, Bornehag CG, Bornman R, Brandt I, Brian JV et al. Science and policy on endocrine disrupters must not be mixed: a reply to a "common sense" intervention by toxicology journal editors. Environmental Health 201312 69. (doi:10.1186/ 1476-069X-12-69)

Received 14 September 2013

Accepted 14 September 2013 